\title{
Mesohabitat heterogeneity in four mediterranean streams of the Jucar river basin (Eastern Spain)
}

\author{
Juan Diego Alcaraz-Hernández ${ }^{1, *}$, Francisco Martínez-Capel ${ }^{1}$, Matías Peredo-Parada ${ }^{2}$ and \\ Aina B. Hernández-Mascarell ${ }^{3}$
}

${ }^{1}$ Institut d'Investigació per a la Gestió Integrada de Zones Costaneres (IGIC), E.P.S. de Gandia (Universitat Politècnica de València). C/Paranimf 1, 46730 Grao de Gandia. Valencia (Spain). E-mail: fmcapel@ dihma.upv.es.

2 Plataforma de Investigación en Ecohidrología y Ecohidráulica (EcoHyd). Almirante Riveros \# 075. Santiago. Chile.

${ }^{3}$ TECNOMA, S.A. c/ Antiga Senda de Senent, 11-3º 46023 Valencia, Spain.

* Corresponding author: jdalcaraz@ gmail.com

Received: 18/10/2010

Accepted: 9/6/2011

\begin{abstract}
Mesohabitat heterogeneity in four mediterranean streams of the Jucar river basin (Eastern Spain)

The hydromorphological units or mesohabitats of the headwaters of four Mediterranean streams were studied by classifying them according to their length, width, average and maximum depth, percentage of substrate and water volume. These characteristics of the streams were assessed over four consecutive years (2003-2006). The main objective of the study was to analyse the spatial and temporal pattern of the physical attributes of the mesohabitats. Classification strength and dendrograms were examined for each stream, mesohabitat type, and combination of stream and mesohabitat type and for stream mesohabitat type and year, whereas Nonmetric Multidimensional Scaling ordination (NMDS) was used to analyse classification patterns. The Villahermosa and Ebrón streams were more homogeneous than the Palancia and Vallanca streams, whereas riffles and glides were more homogeneous than pools and rapids. The NMDS indicated that the slow water-velocity (pools, glides) and fast (riffles, rapids) mesohabitats tended to group together. Temporally, the Ebrón stream pools were homogeneous and very stable over the four years, whereas the Vallanca and Villahermosa pools showed a certain degree of variability. The Palancia pools were the most variable and heterogeneous during the study period. These results underscored the importance of separating different types of deep, slow-velocity habitats in mesohabitat inventories and the importance of evaluating habitat classifications in eco-hydromorphological and hydrobiological studies, especially in Mediterranean streams and rivers.
\end{abstract}

Key words: Mediterranean streams, hydromorphological units, mesohabitat, habitat classification, similarity, Iberian Peninsula.

\section{RESUMEN}

\section{Heterogeneidad del mesohábitat en cuatro ríos mediterráneos de la cuenca del río Jucar (Este de España)}

Las unidades hidromorfológicas o mesohábitats de cuatro ríos mediterráneos de cabecera fueron estudiadas en función de su longitud, anchura, profundidad media y máxima, porcentaje de sustrato y volumen de cada mesohábitat durante cuatro años consecutivos (2003-2006). El objetivo principal fue analizar la variación espacio-temporal de los diferentes mesohábitat según sus atributos físicos. La fortaleza de la clasificación y su dendrograma se examinó según cada río, cada tipo de mesohábitat, una combinación de cada río y tipos de mesohábitats y según cada río y tipos de mesohábitats de los cuatro años de muestreo. El Escalado Multidimensional No Métrico (NMDS) se usó para analizar los patrones de las clasificaciones. El NMDS indicó que tanto los mesohábitats lentos (pozas y tablas) como los mesohábitats rápidos (corrientes y rápidos) tienden a agruparse juntos. Desde la una perspectiva temporal, las pozas del río Ebrón fueron homogéneas y muy estables durante los cuatro años de muestreo, mientras que las pozas de los ríos Vallanca y Villahermosa mostraron un cierto grado de variabilidad y las del río Palancia fueron las más variables y heterogéneas durante el periodo de estudio. Los resultados destacan la importancia de diferenciar distintos tipos de hábitats lentos en los inventarios de mesohábitat, y la importancia de evaluar las clasificaciones de los mesohábitats en estudios de eco-hidromorfología e hidrobiología, especialmente los desarrollados en ríos mediterráneos. 
Palabras clave: Ríos mediterráneos, unidades hidromorfológicas, mesohábitat, clasificación de hábitats, similaridad, Península Ibérica.

\section{INTRODUCTION}

Understanding and predicting the key factors that organise fluvial ecosystems and the ways that these factors influence hydrological and hydraulic characteristics and the organisms present is essential for those who study, manage, and use river services (Wang et al., 2006). Accordingly, in recent decades, a multitude of river classification methods have been developed as an aid to understand natural spatiotemporal patterns in rivers and to improve management and comply with legislation requirements (Brenden et al., 2008). One of the main advances has been the need to clearly recognise different spatial scales when studying habitat and biological characteristics in rivers (Hayes et al., 2003). To achieve this goal, studies seeking relationships between fluvial habitat characteristics and aquatic organisms follow a hierarchical approach (González del Tánago \& García de Jalón, 2006) in which the characteristics of the watershed, fluvial segment, reach, mesohabitat and microhabitat should all be considered (Frissell et al., 1986).

The classification of mesohabitats has become an important process for structuring physical habitat surveys in large river segments and at a river network scale (Williams et al., 2004). The characteristics of river catchments, segment and reaches have been widely described and used to classify river ecosystems (Bisson et al., 2006), whereas mesohabitat characteristics have been used much less for this purpose. This lack of emphasis could be a direct consequence of the difficulty of objectively describing or classifying mesohabitats (e.g., pools, glides, riffles, or rapids). Mesohabitat description was first developed in the United States at the beginning of the 1980s and further improved during the 1990s (Bisson et al., 1982; Frissell et al., 1986; Hankin \& Reeves, 1988; Hawkins et al., 1993; Flosi
\& Reynolds, 1994; Roper \& Scarnecchia, 1995; Vadas \& Orth, 1998). These advances resulted in the development of various national sampling programs that recognised different types of mesohabitats (e.g., Sowa et al., 2005; Stoddard et al., 2005; Seelbach et al., 2006).

The mesohabitat scale is becoming more important because of its use in environmental flow studies (Parasiewicz, 2007; Parasiewicz et al., 2009; Schneider et al., 2010) and because of the importance of mesohabitat characteristics as proximate variables for many aquatic organisms. Numerous studies have successfully related mesohabitat characteristics to macroinvertebrate community composition (Brown \& Brussock, 1991; Pardo \& Armitage, 1997; Beisel et al., 1998) or to fish assemblages (Modde et al., 1991; Erös \& Grossman, 2005; Schwartz \& Herricks, 2008). Moreover, in Europe, the Water Framework Directive (European Commission, 2000) required all member states to develop programs to monitor surface waters. Hydromorphological conditions play an important role in these monitoring programs (REFCOND, 2003; CEN, 2004). Consequently, many countries now have sampling protocols and indices that require information on mesohabitat recognition and characterisation to evaluate hydromorphological conditions (e.g., Raven et al., 1997; LAWA, 2000; Tickner et al., 2000; Pardo et al., 2002; Fernández et al., 2011).

Despite the increasing interest in analysis on the mesohabitat scale and in mesohabitat characteristics, few studies have tested the reliability of mesohabitat classifications (Thomson et al., 2004; Clifford et al., 2006; Schwartz \& Herricks, 2008) or have studied the spatial and temporal variability of mesohabitat characteristics (Hilderbrand et al., 1999; Trainor \& Church, 2003). Methodological and theoretical problems related to the identification of mesohabitats and transferability among rivers still need to be solved (Clif- 
ford et al., 2006). Thus, the concept of mesohabitat and its focal topics require further improvement (Harvey \& Clifford, 2009).

In this study, the Basinwide Visual Estimation Technique (BVET, Dollof et al., 1993) was adapted and applied to survey mesohabitat types in Mediterranean headwater streams. This technique consists of classifying and characterising mesohabitats based on their physical characteristics according to previously defined rules. This approach is therefore considered to represent an $a$ priori classification (sensu Snelder et al., 2005). Thus, the habitats belonging to each mesohabitat type might exhibit a certain degree of heterogeneity, and it is convenient to analyse the similarity of the different elements within and among mesohabitat types in order to evaluate how well the classification matches the variability among physical mesohabitat characteristics (Snelder et al., 2005). The main objective of this study was to evaluate the mesohabitat classification implemented in the field and the spatial and temporal variability of those mesohabitat types or hydromorphological units. Specifically, we compared the patterns of spatial and temporal variability shown by mesohabitat types and rivers, based on mesohabitat-scale physical characteristics.

\section{METHODS}

\section{Study area}

The study sites are located in the headwaters of the Ebrón, Vallanca, Palancia and Villahermosa streams in the Comunitat Valenciana (Eastern Spain; Fig. 1) at elevations ranging from 575 to $951 \mathrm{~m}$ above sea level. No reservoirs or dams

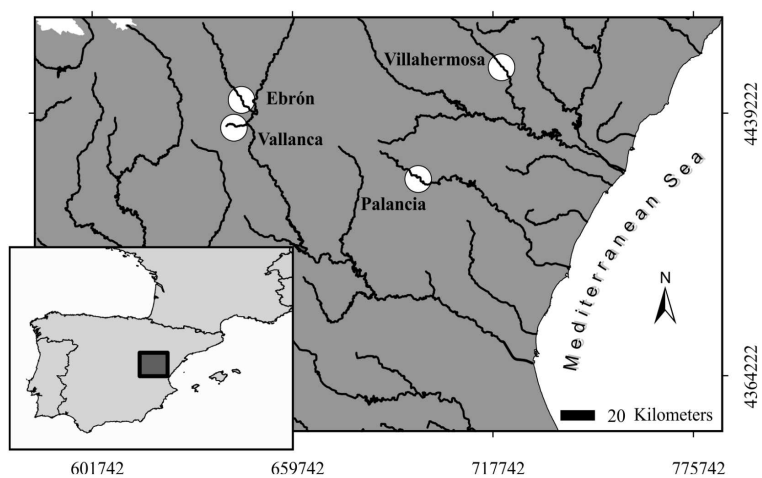

Figure 1. Location of the sampling sites in 4 streams of the Jucar River Basin, Spain. Localización de los tramos de muestreo en ríos de la cuenca del Júcar, España.

are present upstream from the study sites. The stream order (Strahler, 1957) of the Ebrón and Vallanca streams is 2, and that of the Palancia and Villahermosa streams is 3 (Table 1). They are narrow streams (mean width from 2.5 to $5.7 \mathrm{~m}$ ) with small mean water depths ranging from 0.3 to $0.5 \mathrm{~m}$. The slope is relatively high and averages $21.8 \mathrm{~m} \cdot \mathrm{km}^{-1} \pm 4.8$ (S.D.) for the four streams. The smallest watershed area is $55 \mathrm{~km}^{2}$ in the highest segment of the Vallanca stream, and the largest is $268 \mathrm{~km}^{2}$ in the lowest segment of the Villahermosa stream (Mouton et al., 2011). The average flow rate of the streams during the survey (July) showed a heterogeneous pattern (Table 2). The Ebrón had the largest range of flow rates, between 0.635 and $1.404 \mathrm{~m}^{3} \cdot \mathrm{s}^{-1}$. In contrast, the Palancia had a range of flow rates of only 0.019 to $0.209 \mathrm{~m}^{3} \cdot \mathrm{s}^{-1}$.

The origin of these streams is in the calcareous mountains of the Iberian range. The water in the streams is therefore basic $(\mathrm{pH}=7.9$ \pm 0.2 ). Three of the streams are tributaries of

Table 1. Average width, depth and slope estimated for the four segments in each of the studied streams and mean annual discharge, Strahler order and watershed area for each stream. Características físicas principales de los cuatro ríos de estudio, estimadas como media de los segmentos en cada río (anchura media, profundidad media, pendiente media) y a la escala de cada río (caudal medio anual, orden de Strahler, área de la cuenca).

\begin{tabular}{lcccccc}
\hline $\begin{array}{c}\text { Stream } \\
\text { name }\end{array}$ & $\begin{array}{c}\text { Mean } \\
\text { width } \mathbf{( m )}\end{array}$ & $\begin{array}{c}\text { Mean } \\
\mathbf{d e p t h}(\mathbf{m})\end{array}$ & $\begin{array}{c}\text { Mean slope } \\
\left(\mathbf{m} \cdot \mathbf{K m}^{\mathbf{- 1}}\right)\end{array}$ & $\begin{array}{c}\text { Mean annual } \\
\text { discharge }\left(\mathbf{m}^{\mathbf{3}} \cdot \mathbf{s}^{\mathbf{- 1}}\right)\end{array}$ & $\begin{array}{c}\text { Strahler } \\
\text { Order }\end{array}$ & $\begin{array}{c}\text { Watershed area } \\
\left(\mathbf{K m}^{\mathbf{2}}\right)\end{array}$ \\
\hline Ebrón & 4.58 & 0.37 & 14.2 & 1.13 & 2 & 250 \\
Vallanca & 2.51 & 0.26 & 13.6 & 0.35 & 2 & 123 \\
Palancia & 5.66 & 0.49 & 16.8 & 0.26 & 3 & 204 \\
Villahermosa & 5.40 & 0.28 & 23.0 & 1.08 & 3 & 268 \\
\hline
\end{tabular}


Table 2. Mean July flow rate $\left(\mathrm{m}^{3} \cdot \mathrm{s}^{-1}\right)$ for each stream for the 2003, 2004, 2005, and 2006 field seasons. Caudales medios del mes de Julio $\left(\mathrm{m}^{3} \cdot \mathrm{s}^{-1}\right)$ correspondientes a cada río de estudio, para las cuatro campañas de muestreo, en 2003, 2004, 2005 y 2006.

\begin{tabular}{lllll}
\hline & $\mathbf{2 0 0 3}$ & $\mathbf{2 0 0 4}$ & $\mathbf{2 0 0 5}$ & $\mathbf{2 0 0 6}$ \\
\hline Ebrón & 1.404 & 1.374 & 0.635 & 0.665 \\
Vallanca & 0.422 & 0.373 & 0.123 & 0.175 \\
Palancia & 0.049 & 0.209 & 0.019 & 0.045 \\
Villahermosa & 0.105 & 0.407 & 0.034 & 0.224
\end{tabular}

* The Palancia stream could not be sampled in 2003.

larger rivers. Only the Palancia empties directly into the Mediterranean Sea. The four watersheds consist primarily of forest $(84 \%)$, with the remaining $16 \%$ consisting of agricultural and urbanised areas (Alcaraz-Hernández et al., 2007). The estimated mean annual flow rates are $1.13,1.08,0.35$ and $0.26 \mathrm{~m}^{3} \cdot \mathrm{s}^{-1}$ for the Ebrón, Villahermosa, Vallanca and Palancia streams, respectively, based on hydrological modelling performed by the Jucar River Basin Authority (1940-2006). The riparian vegetation includes willows (Salix atrocinerea, S. eleagnos, S. alba and $S$. fragilis), poplars (Populus nigra and $P$. alba) and elms (Ulmus minor), in the order Populetalia albae (Costa, 1999). Brown trout (Salmo trutta) dominate fish communities in the 4 streams. These fish communities also include other native (Anguilla anguilla, Luciobarbus guiraonis, Barbus haasi, Achondrostoma arcasii, Squalius valentinus) and exotic (Oncorhynchus mykiss) fish species.

\section{Data collection}

For the purposes of this study, we define a hydromorphological unit (HMU) as an area of water delimited by abrupt gradient changes on the water surface and by abrupt changes related to hydraulic controls. An HMU exhibits distinctive hydraulic properties and a characteristic channel cross-section (Dollof et al., 1993; Parasiewicz et $a l ., 2009)$. This concept is similar to the mesohabitat concept previously used in other studies (Vadas \& Orth, 1998; Tickner et al., 2000; Schwartz \& Herricks, 2008). In this paper, we treat mesohabitat and hydromorphological unit as synonyms.
All of the mesohabitats at each study site were identified and characterised during July at base flow from 2003 through 2006 in the four Mediterranean streams of the Jucar River Basin selected for this study (Fig. 1). The minimum and maximum acceptable river reach lengths for surveying mesohabitats depend on the bankfull width. These values have been defined as $150 \mathrm{~m}$ (minimum) and 300-500 m (maximum) for wadeable sites (Meador et al., 1993). To avoid underestimating mesohabitat types, we selected $300 \mathrm{~m}$ as the reach length for this study. In each reach, all mesohabitats were identified and surveyed until the minimum length of $300 \mathrm{~m}$ was achieved. During the first year of the study, data were collected in the Ebron, Vallanca and Villahermosa. The Palancia was included in the second year. During 2003, only 2 reaches were surveyed in each stream, whereas 4 reaches per stream were surveyed in the following years. A severe drought occurred during the last 2 years of the study, and the farthest-upstream reaches of the Vallanca and Villahermosa were dry. In all, 50 reaches were surveyed during the entire study period. The reaches in the same stream were an average of $2600 \mathrm{~m}$ apart. The minimum and maximum distances of separation were 1470 and $4600 \mathrm{~m}$, respectively.

Each mesohabitat was characterised by adapting the sampling protocol of the Basinwide Visual Estimation Technique (BVET; Hankin \& Reeves, 1988; Dolloff et al., 1993). This protocol has been applied by the U.S. Forest Service for the identification of habitat and for the sampling of salmonid populations in large river networks. The technique is applied by visually stratifying the river according to its different biotopes (mesohabitats) and recording their main physical characteristics (length, mean water width, mean water depth and substrate). In this study, we defined only four types of mesohabitats: pools, glides, riffles and rapids. Other types of habitat units, such as cascades or steps, were not included in this study. The following hydraulic criteria were used to identify the four types of mesohabitats:

- Pools (P) have a water depth greater than $0.6 \mathrm{~m}$ (generally produced by local erosion), 
a water velocity below the average for the reach, and a very low longitudinal gradient.

- Glides (G) have a water depth greater than $0.6 \mathrm{~m}$, a water velocity similar to the average for the reach, little turbulence and nearly symmetrical cross sections.

- Riffles (Ri) have shallow water with ripples on the surface, an average water velocity less than $0.4 \mathrm{~m} \cdot \mathrm{s}^{-1}$, nearly symmetrical cross sections, and a mean depth similar in magnitude to the mean substrate size.

- Rapids (Ra) have shallow water with water velocity greater than the average for the section, abundant surface turbulence, elements of coarse substrate projecting from the water surface, and a predominance of supercritical flow.

Additionally, in each mesohabitat, the following variables were measured: (1) mesohabitat length $(\mathrm{m})$; (2) average surface water width (m), obtained from three cross sections corresponding to $1 / 4,1 / 2$, and $3 / 3$ of the total length of the mesohabitat; (3) mean depth (m), calculated from nine points corresponding to measurements taken at each cross section where the water width was estimated; and (4) maximum depth (m). Moreover, water volume $\left(\mathrm{m}^{3}\right)$ was derived from the previous variables. The percentages of substrate types were visually estimated in the field, using a simplified version of the method used by Platts et al. (1983), i.e., bedrock, large boulders (> $1024 \mathrm{~mm}$ diameter), boulders (1024-256 mm), cobbles $(256-64 \mathrm{~mm})$, gravel $(64-8 \mathrm{~mm})$, fine gravel $(8-2 \mathrm{~mm})$, sand $(2 \mathrm{~mm}-62 \mu \mathrm{m})$, and lime and clay $(<62 \mu \mathrm{m})$. These substrate percentages were reclassified into coarse $(>256 \mathrm{~mm}$ in diameter), medium (2-256 mm), and fine substrate $(<2 \mathrm{~mm})$ for the data analyses presented here.

\section{Data analysis}

The first step to define the habitat characteristics of the study sites at a mesohabitat scale was to summarise the results for length, mean width, mean and maximum depth, and volume by mesohabitat type and stream. For each characteristic analysed, the statistic used to define the loca- tion (central tendency) of the data distribution was Huber's estimator, Tn, and the robust estimator used to define the spread (variability) of the distribution was the Normalised Median Absolute Deviation (NMAD).

Four a priori classifications were established to analyse mesohabitat heterogeneity in space and time. From a spatial perspective, three classifications were developed: (1) by stream, grouping together all mesohabitats occurring in the Ebrón (EB), Vallanca (VA), Palancia (PA), and Villahermosa (VI) streams; (2) by mesohabitat, grouping together all mesohabitats into pool $(\mathrm{P})$, glide $(\mathrm{G})$, riffle (Ri), and rapid (Ra); and (3) by stream-mesohabitat, a combination of both of the preceding classifications. The classes were coded using the stream and the mesohabitat name (e.g., Vallanca-Pools as VA-P). From a temporal perspective (inter-year comparison), one a priori classification was evaluated (4) by streammesohabitat-year, with the stream-mesohabitat classes separated by year.

The similarity within each classification was examined with the classification strength test developed by Van Sickle (1997). A proximity matrix was built based on the mesohabitat physical characteristics for each of the 4 classifications defined above. Euclidean distances were calculated for all the possible pairwise combinations of elements in each classification. The classes for which only one data point was available were discarded. The distance between the individual observations in rows $i=\left(x_{i 1}, x_{i 2}, \ldots, x_{i p}\right)$ and $j=\left(x_{j 1}, x_{j 2}, \ldots, x_{j p}\right)$ is defined by

$$
d_{j k}=\sqrt{\sum_{i=1}^{p}\left(x_{i j}-x_{i k}\right)^{2}}
$$

The classification strength test compares the grouping within each class with the mean distance between classes and involves determining the internal similarity distance for each class $\left(\bar{W}_{i}\right)$, the intra-class mean distance $(\bar{W})$ and the inter-class mean distance $(\bar{B})$. The ratio $M=\bar{W} / \bar{B}$ provides an estimate of the strength of the classification developed (Van Sickle, 1997). Ratios equal to 1 indicate that there is no classification structure $(\bar{B}=\bar{W})$. The lower the ra- 
tio, the higher the classification structure. Classes having values of $\bar{W}_{i}$ close to 0 are more homogeneous, and classes with values of close to 1 are more heterogeneous. The statistical significance of the test was determined with a randomisation procedure $(n=1000, p<0.001)$ based on the null hypothesis of no classification structure, using the bootstrap technique without replacement (Goslee \& Urban, 2007).

Mean-distance dendrograms were used to plot the classification results (Van Sickle \& Hughes, 2000). These plots are trees with a vertical main stem located at the mean inter-class distance $(\bar{B}$ on the horizontal axis. Each class is represented as a horizontal branch coming out of the main stem, with the end marking the mean intra-class distance $\left(\bar{W}_{i}\right)$. Therefore, the length of a branch (class $i$ ) represents the difference between the mean inter-classes and the mean intra-class sim- ilarity $\left(\bar{B}-\bar{W}_{i}\right)$. A larger branch to the left side of the main stem means that a class is both more internally homogeneous and farther from the mean of all the groups and that the classification is more robust. The classification strength test was performed using the EnvClass procedure, programmed by Snelder et al. (2009), in the R statistical package.

Patterns in the stream-mesohabitat classes were further investigated with a Non-Metric Multidimensional Scaling ordination (NMDS) with Euclidean distance to determine the similarity matrix based on the physical characteristics of the mesohabitats. The NMDS is an ordination technique that positions objects in a reduced multidimensional space according to the similarity range of pairs of objects in the proximity matrix (Digby \& Kempton, 1987). Points that are closer together in the ordination correspond to elements that are

Table 3. Summary of the mesohabitat characteristics by stream and mesohabitat type in terms of length (m), mean width (m), mean depth $(\mathrm{m})$, maximum depth $(\mathrm{m})$, and volume $\left(\mathrm{m}^{3}\right)$. The robust descriptive statistics used were Tn (Huber's estimator) and NMAD (in brackets). Sumario de las características de los mesohábitats muestreados, por río y tipo de mesohabitat, mediante su longitud $(m)$, anchura media $(m)$, calado medio $(m)$, calado máximo $(m)$ y volumen $\left(m^{3}\right)$. Los descriptores estadísticos robustos fueron Tn (estimador de Huber) y el NMAD (en paréntesis).

\begin{tabular}{|c|c|c|c|c|}
\hline & $\begin{array}{l}\text { EBRÓN } \\
(\mathrm{N}=188)\end{array}$ & $\begin{array}{l}\text { VALLANCA } \\
\qquad(\mathbf{N}=\mathbf{4 1 3})\end{array}$ & $\begin{array}{l}\text { PALANCIA } \\
\quad(\mathbf{N}=\mathbf{2 0 5})\end{array}$ & $\begin{array}{l}\text { VILLAHERMOSA } \\
(\mathbf{N}=\mathbf{1 5 8})\end{array}$ \\
\hline \multicolumn{5}{|l|}{ Pool } \\
\hline Length & $20.88(7.12)$ & $14.49(8.82)$ & $21.74(13.49)$ & $29.06(16.08)$ \\
\hline Width & $4.57(1.23)$ & $2.86(0.79)$ & $6.09(1.61)$ & $5.84(1.54)$ \\
\hline Mean Depth & $0.45(0.15)$ & $0.42(0.18)$ & $0.61(0.16)$ & $0.43(0.13)$ \\
\hline Max. Depth & $0.98(0.30)$ & $0.70(0.21)$ & $1.10(0.28)$ & $0.97(0.32)$ \\
\hline Volume & $45.46(30.27)$ & $17.43(11.36)$ & $86.41(62.57)$ & 75.05 (45.99) \\
\hline \multicolumn{5}{|l|}{ Glide } \\
\hline Length & $19.38(4.60)$ & 11.85 (5.19) & 23.77 (10.38) & $31.45(14.01)$ \\
\hline Width & $4.45(1.80)$ & $2.23(0.51)$ & $4.17(0.68)$ & $5.46(1.74)$ \\
\hline Mean Depth & $0.31(0.14)$ & $0.21(0.11)$ & $0.39(0.16)$ & $0.25(0.07)$ \\
\hline Max. Depth & $0.62(0.29)$ & $0.37(0.16)$ & $0.56(0.08)$ & $0.52(0.13)$ \\
\hline Volume & $29.43(25.27)$ & $6.14(4.32)$ & $37.62(19.38)$ & $44.96(25.52)$ \\
\hline \multicolumn{5}{|l|}{ Riffle } \\
\hline Length & $30.06(18.38)$ & $10.02(4.74)$ & $18.54(8.90)$ & $27.02(16.75)$ \\
\hline Width & $4.51(1.47)$ & $2.30(0.56)$ & $4.34(0.95)$ & $5.25(1.29)$ \\
\hline Mean Depth & $0.28(0.07)$ & $0.18(0.07)$ & $0.37(0.12)$ & $0.21(0.06)$ \\
\hline Max. Depth & $0.49(0.24)$ & $0.31(0.12)$ & $0.57(0.16)$ & $0.38(0.13)$ \\
\hline Volume & $45.61(39.82)$ & $4.84(3.51)$ & 30.38 (18.76) & $29.20(17.23)$ \\
\hline \multicolumn{5}{|l|}{ Rapid } \\
\hline Length & $23.93(11.26)$ & $8.95(4.82)$ & $14.66(8.60)$ & $16.83(8.90)$ \\
\hline Width & $4.57(1.71)$ & $2.59(0.70)$ & $4.89(0.79)$ & $4.72(1.32)$ \\
\hline Mean Depth & $0.38(0.13)$ & $0.28(0.07)$ & $0.37(0.18)$ & $0.20(0.06)$ \\
\hline Max. Depth & $0.60(0.21)$ & $0.46(0.08)$ & $0.61(0.21)$ & $0.34(0.10)$ \\
\hline Volume & $38.30(18.12)$ & 7.19 (5.66) & $25.21(13.58)$ & $17.08(12.14)$ \\
\hline
\end{tabular}


more similar to each other. Initial examinations of the stress patterns in the data suggested that two dimensions were appropriate for the final ordination. The dimensions were established after fewer than 10 iterations of the procedure.

\section{RESULTS}

During the four years of the study (2003-2006), a total of 964 habitat units were sampled in the four streams. The general characterisation of the mesohabitats is shown in Table 3. The three tests based on the null hypothesis of no spatial classification structure were statistically significant $(p<0.001)$. The 3-part classification that we defined was therefore robust. However, the indicator of classification strength (M) did not yield high values. The classification strength (M) was 0.87 for classification by stream

(a) Classification by river

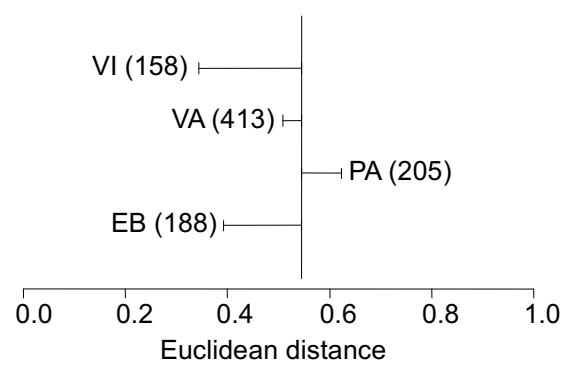

(b) Classification by mesohabitat

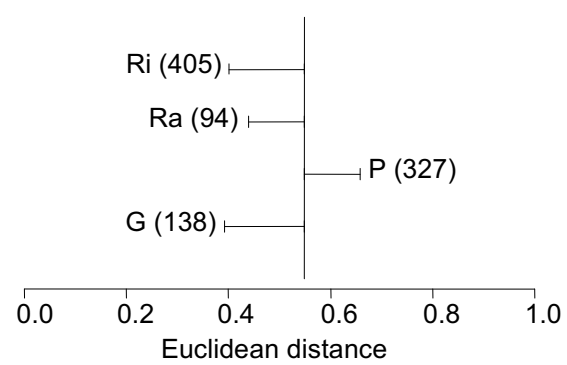

$(\bar{B}=0.55, \bar{W}=0.48), 0.89$ for classification by mesohabitat $(\bar{B}=0.55, \bar{W}=0.49)$, and 0.80 for classification by stream-mesohabitat $(\bar{B}=0.54$, $\bar{W}=0.43)$. The dendrogram branches were irregular or heterogeneous in the classification by stream (Fig. 2.a). This result indicates that the mesohabitats in the Villahermosa and the Ebrón were more homogeneous (with larger branches to the left) than those in the Vallanca and the Palancia (Fig. 2.a). Furthermore, glides, riffles and rapids were more uniform (lower $\bar{W}_{i}$ ) than pools (higher $\bar{W}_{i}$; Fig. 2.b).

The within-class heterogeneity was generally lower than the mean inter-class heterogeneity $\left(\bar{W}_{i}\right.$ lower than $\bar{B}$ ) for the stream-mesohabitat classes (Fig. 2.c). Riffles and glides from the Villahermosa, the Ebrón and the Vallanca were more homogeneous than pools and rapids, whereas the Vallanca and Palancia pools were the most heterogeneous $\left(\bar{W}_{i}\right.$ values higher than $\left.\bar{B}\right)$. The rif-

(c) Classification by river-mesohabitat

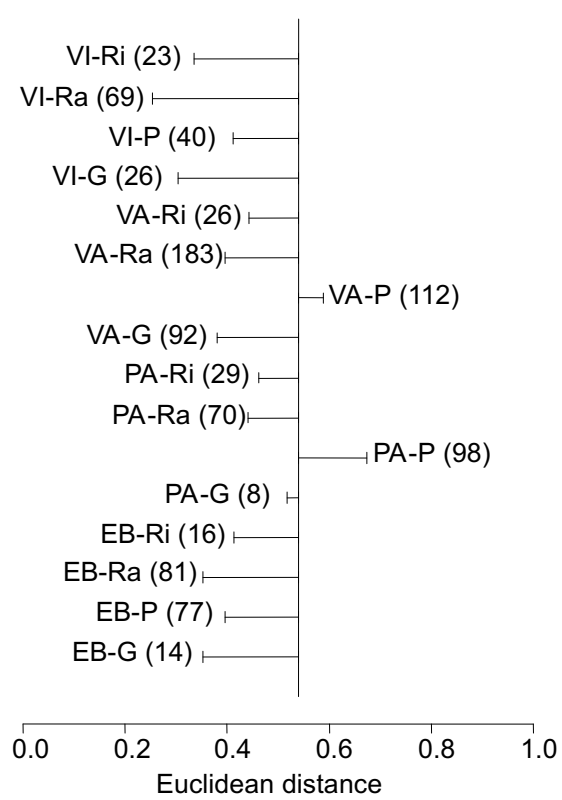

Figure 2. Classification dendrograms for the tests of the (a) stream, (b) mesohabitat, and (c) stream-mesohabitat classes. The distance $\bar{B}$ is indicated at the base of the trunk (vertical line), whereas the distances $\bar{W}_{i}$ are represented by the ends of the branches (horizontal lines). The sample size of each group is shown in brackets (Villahermosa: VI; Vallanca: VA; Palancia: PA; Ebrón: EB; glide: G; rapid: Ra; pool: P; riffle: Ri). Dendrogramas obtenidos a partir del test de clasificación para las distintas clases establecidas (a) río, (b) mesohábitat y (c) río-mesohábitat. La distancia $\overline{\mathrm{B}}$ está representada por la base del tronco (línea vertical), mientras que las distancias $\overline{\mathrm{W}}_{\mathrm{i}}$ las representan los extremos de las ramas (líneas horizontales). Entre paréntesis se indica el tamaño de muestra de cada grupo (Villahermosa, VI; Vallanca, VA; Palancia, PA; Ebrón, EB; tabla, G; rápido, Ra; poza, P; corriente, Ri). 


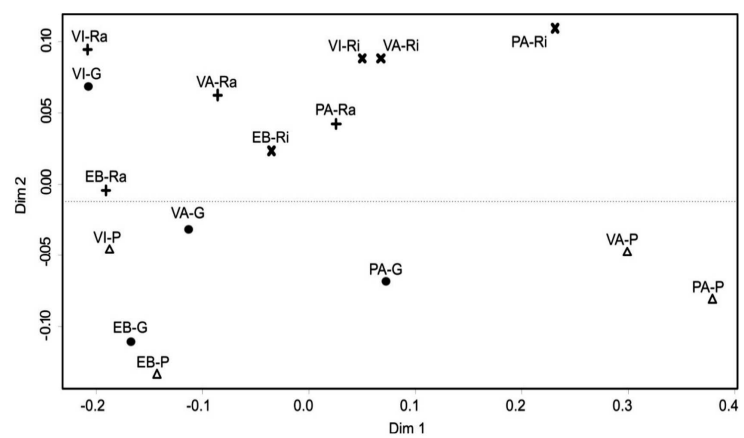

Figure 3. Nonmetric Multidimensional Scaling (NMDS) plot of axis 1 and axis 2 for mesohabitats surveyed in July from 2003 to 2006 in the Ebrón (EB), Palancia (PA), Vallanca (VA), and Villahermosa (VI) streams, province of Valencia, Eastern Spain (Glide: $\bullet$ G; rapid: + Ra; pool: $\Delta \mathrm{P}$; riffle: $\times \mathrm{Ri}$ ). Gráfico del Escalado Multidimensional No Métrico (NMDS) con los resultados del eje 1 vs los resultados eje 2 para los mesohábitats muestreados en Julio del 2003 al 2006 en los ríos Ebrón (EB), Palancia (PA), Vallanca (VA) y Villahermosa (VI) (Tabla: • G; rápido: + Ra; poza: $\Delta P$; corriente $: \times R i)$.
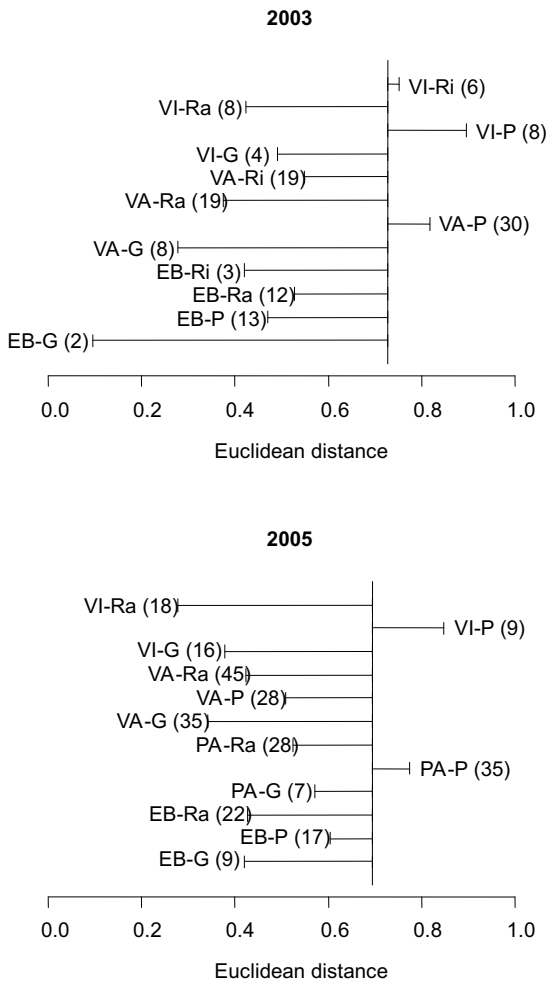

fles, glides and rapids of the Villahermosa and the glides and riffles of the Ebrón were the most homogeneous of all the stream-mesohabitat classes.

No clear grouping among the stream, mesohabitat and stream-mesohabitat classes was observed in the NMDS ordination (Fig. 3). However, the NMDS grouped VI-Ra and VI-G at the top left of the ordination, whereas VA-P and PA-P were located together at the bottom right. In general, fast-water mesohabitats (riffles and rapids) were positively correlated with axis 2 of the ordination and formed a more compact group than slow-water mesohabitats (pools and glides).

The class structure for the stream-mesohabitat-year classification was also significant $(p<0.001)$. However, the classification strength (M) was low. The values of the classification strength were 0.77 in $2003(\bar{B}=0.73$,
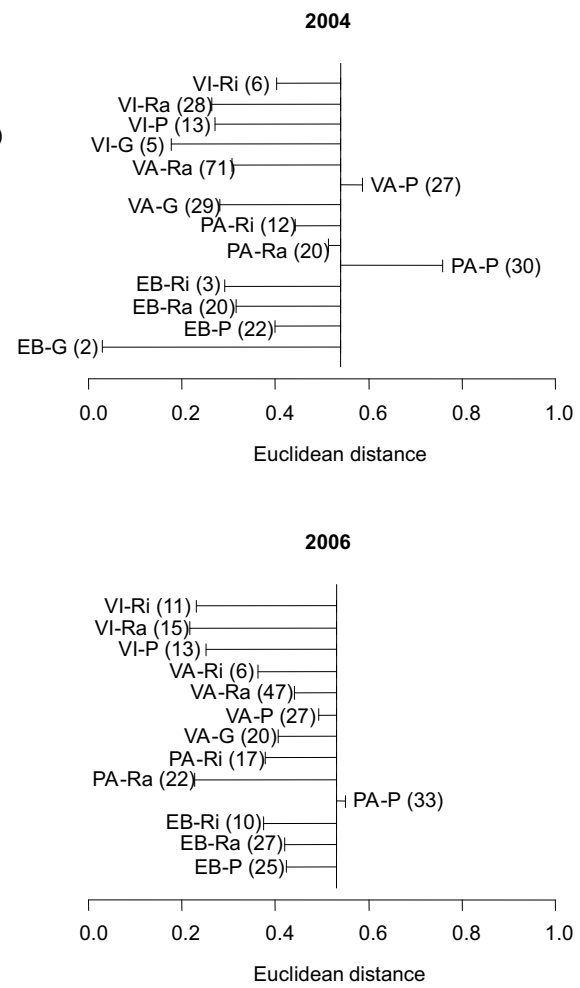

Figure 4. Classification dendrograms for the tests of the stream-mesohabitat-year classes. The distance $\bar{B}$ is indicated at the base of the trunk (vertical line), whereas the distances $\bar{W}_{i}$ are represented by the ends of the branches (horizontal lines). The sample size of each group is shown in brackets (Villahermosa: VI; Vallanca: VA; Palancia: PA; Ebrón: EB; glide: G; rapid: Ra; pool: P; riffle: Ri) for the years 2003, 2004, 2005 and 2006. Dendrogramas obtenidos a partir del test de clasificación para las distintas clases establecidas río-mesohábitat-año. La distancia $\overline{\mathrm{B}}$ está representada por la base del tronco (línea vertical), mientras que las distancias $\overline{\mathrm{W}}_{\mathrm{i}}$ las representan los extremos de las ramas (líneas horizontales). Entre paréntesis se indica el tamaño de muestra de cada grupo (Villahermosa, VI; Vallanca, VA; Palancia, PA; Ebrón, EB; tabla, G; rápido, Ra; poza, P; corriente, Ri) para los años 2003, 2004, 2005 y 2006. 
$\bar{W}=0.56), 0.74$ in $2004(\bar{B}=0.54, \bar{W}=0.4)$, 0.71 in $2005(\bar{B}=0.69, \bar{W}=0.49)$ and 0.75 in $2006(\bar{B}=0.53, \bar{W}=0.4)$. The dendrogram of 2003 has no branch for the Palancia because it was not possible to survey this stream. The riffles of the Vallanca in 2004 and the glides of the Ebrón, the Palancia and the Villahermosa in 2006 are not represented because the data included only 1 instance of each of these cases.

The dendrogram for 2003 showed that all classes had smaller heterogeneity than the mean inter-class heterogeneity (all branches occurred on the left side of the dendrogram), except for VI-Ri, VI-P and VA-P, which were more heterogeneous than the mean (Fig. 4). In the following years, the pools were very heterogeneous, especially VA-P and PA-P in 2004, VI-P and PA-P in 2005 , and PA-P in 2006. Therefore, the pools in the Ebrón were stable and homogeneous during the 4 years, whereas the pools in the Vallanca and Villahermosa showed conditions that varied during the four years. The pools in the Palancia had larger values of heterogeneity for the period of study.

\section{DISCUSSION}

This article presents the evaluation of an a priori mesohabitat classification applied to four Mediterranean streams. The analysis presented was based on the variability in the mean depth, water velocity and cross-sectional form of the mesohabitats. One of the primary criticisms of the mesohabitat-scale approach is that its theoretical definitions may be difficult to apply in the field (Williams et al., 2004). However, the 4 mesohabitat classes used in this study successfully distinguished the main mesohabitat types found in the Mediterranean streams included in the analysis.

This work was based on protocols extensively applied in rivers of the USA (Dollof et al., 1993). In some of these studies, only three types of mesohabitats were used, i.e., pool, riffle and cascade. These authors decided not to use other classifications or subcategories because differences among mesohabitats relied on personal interpretations of subtle variations in mesohabitat char- acteristics. Thus, the use of only 3 mesohabitat types assured that the classifications were unambiguous and mutually exclusive, thereby allowing comparisons of data collected by different observers on the same river and comparisons of characteristics between rivers (Dollof et al., 1993). Jowett (1993) proposed a simple classification of 3 mesohabitat types (pool, run, riffle) that were relatively easy to distinguish visually, based on the hydraulic characteristics of New Zealand rivers. For these reasons, we chose to identify only four mesohabitat types in this study. The classification that we used involved a simplification of the protocols applied by Dollof to rivers inhabited by salmonids, in which pool, glide, riffle, rapid, cascade, and step were distinguished (Instructions for the physical and biological summer surveys for the Elk River, unpublished). In the four streams of Valencia included in the current study, the cascades and steps were very short (with a length considerably smaller than the mean wetted channel width), or their proportion was negligible.

The large number of mesohabitat types used in some studies (e.g., 18, in Hawkins et al. 1993) indicates the potential complexity of the mesohabitat classification in some rivers. However, it is important to consider the suitable level of classification in relation to the objective of the study to reduce the effort required to conduct habitat monitoring programs. In this study, the use of a small number of mesohabitat types was important for saving time in the field, given that the survey involved an appropriate sampling effort (during the summers of 4 consecutive years) and a limited budget.

Different approaches to classifying mesohabitats are based on different mesohabitat characteristics. Most methods rely on visual estimates of the surface water velocity, e.g., the MesoHABSIM approach (Parasiewicz, 2007; Gortázar et al., 2011), which considers riffle, rapid, cascade, glide, run, fast run, pool, plunge pool, backwater, and side arm mesohabitats. Visual estimation is used in the majority of methods that have attempted to operate at the mesohabitat scale (Bisson et al., 1982, Frissell et al., 1986, Dollof et al., 1993, Hawkins et al., 1993). Other approaches 
to the classification of mesohabitats use variables related to riverbed roughness, such as substrate, rather than hydraulic variables. For example, Vadas \& Orth (1998) produced a mesohabitat classification that included seven types of habitat units (deep, medium and shallow pool, deep and medium run, fast and slow riffle). Moreover, Jowett (1993) used only water velocity and depth to provide simple criteria for the objective classification of pool, run and riffle. The Froude number and the ratio of velocity to depth were the best variables for discriminating these mesohabitats. Most of these techniques and methods have been developed and tested in watercourses where the hydromorphological conditions differ greatly from those found in Mediterranean rivers. However, our results show that the four-mesohabitattype classification works reasonably well in four Mediterranean streams and could also be applied to other Mediterranean rivers and streams.

Assessing the applicability of the aforementioned methods is critical for hydro-morphological studies because the assessment of the ecological status of water bodies includes the evaluation of hydro-morphology, water quality, and biological components. Within the hydro-morphological assessment, the use of mesohabitat classifications might be highly relevant for making coherent assessments of the ecological status of Mediterranean rivers. In these environments, several studies have demonstrated the ecological relevance of mesohabitat classifications for aquatic species (e.g., Alcaraz-Hernández et al., 2007, 2009; Alcaraz-Hernández, 2011; Costa et al., in press); however, a larger research effort is necessary.

Using previously established mesohabitat survey methods is a quick and simple way to characterise the physical habitat and allows the stratification and comparison of the physical characteristics of the habitat. The meso-scale survey allows the collection of detailed information on long reaches. Compared with smallscale approaches, this meso-scale method potentially provides highly representative data sets for large study areas despite possible budgetary constraints and is subject to smaller extrapolation errors (Parasiewicz \& Walker, 2007; Gortázar et al., 2011). The sampling of habitats at this scale allows the evaluation of some elements of cover and the consideration of their extent or their specific properties. These elements, e.g., backwaters and undercut banks, are very important for the aquatic fauna (Parasiewicz, 2007; Costa et $a l$. , in press), and they complement the evaluation of depth or velocity that can be implemented at the microhabitat or mesohabitat scale. Furthermore, if the mesohabitat surveys are applied with different representative flow rates, it is possible to simulate diverse scenarios, such as river alterations or restoration measures, e.g., with the MesoHabsim approach (Parasiewicz et al., 2009; Gortázar et al., 2011).

One of the main results of this study is the identification of greater heterogeneity within pool mesohabitats. This result indicates that it would be of interest to include sub-types of pool habitats in the classification of mesohabitats in these four streams and, very possibly, in other similar Mediterranean streams. This addition would require a relatively small increment in field effort, but it would substantially increase the discrimination of different mesohabitat types according to their physical characteristics. In our opinion, the use of 7 basic habitat types (riffle, rapid, glide, 2 types of pools, deep run, and one additional type) could provide a good balance of field effort and data quality for extensive surveys in many Mediterranean streams or rivers of orders from 1 to 4 . In this study, the use of a small number of mesohabitat types was important to save time in the field. However, the number of types and their relevance will vary, e.g., with channel morphology, hydrological conditions, and gradient. The inclusion of other habitat types might be relevant in rivers having other environmental settings.

Pools were the most heterogeneous habitat units, especially in the Vallanca and Palancia (Fig. 2), whereas mesohabitats in the Ebrón and Villahermosa were, in general, more homogeneous. In general, slow-water habitats (pool and glide) and fast-water habitats (riffle and rapid) tended to group together. The fast-water habitats were more homogeneous (Fig. 3). These results are consistent with the findings of other studies (Harvey \& Clifford, 2009) in which pools have 
been found to be hydraulically more complex and to have higher spatial heterogeneity owing to large variations in depth and flow structure. In contrast, Jowett (1993) found that fast-water habitats in New Zealand rivers were more variable than low-velocity habitats and that mistakes in their classification were more frequent. This difference can be explained by the magnitude of the river channel and the mean flow. In the Ashburton River (NZ), the mean flow was considerably larger, i.e., 23,14 and $9.2 \mathrm{~m}^{3} \cdot \mathrm{s}^{-1}$, in the lower, middle, and upper survey reaches, approximately one order of magnitude greater than the values of mean flow for the streams surveyed in Valencia $\left(0.26-1.13 \mathrm{~m}^{3} \cdot \mathrm{s}^{-1}\right)$.

One of the most important criticisms of mesohabitat characterisation is that the habit surveys are conducted in wadeable rivers during periods of low flow (Roper \& Scarnecchia, 1995). The results of hydraulic characterisation under these conditions may not be indicative of the changes in mesohabitat characteristics with flow conditions (Williams et al., 2004). However, Hilderbrand et al. (1999) performed a space-time comparison of a poolriffle sequence during low- and high-flow periods. They found that the total area occupied by pools increases with a reduction in flow because their number increases, although they are smaller. In our study, we did not consider seasonal (intraannual) variability. However, the inter-annual variability was still greatest for the pool mesohabitats (Fig. 4). Our results indicate that this finding might be related to the mean flow rate of the study sites in July (Table 2). The comparison of mean flow by year and stream shows that the largest mean flows occurred in the Ebrón, which also had the more homogeneous pools (Fig. 4). However, the less-stable and more heterogeneous pools were primarily found in the streams with the lowest mean flows, i.e., the Vallanca and the Villahermosa (2003), the Palancia (2004), the Palancia and the Villahermosa (2005), and the Palancia (2006). The only obvious exception to this rule was the Palancia in 2003 because this stream could not be sampled that year. These findings suggest an apparent relationship between the temporal (inter-annual) heterogeneity of pool habitats and the mean flow in the reach.
Given that flow influences the proportions of different mesohabitats, another possible approach to variability analysis is to standardise the habitat dimensions (e.g., width, depth). One basis for such standardisation might be the area of the watershed occupied by each study site. This approach has been used by other studies relating mesohabitats and aquatic species (Costa et al., in press). In this way, the scale effects related to the watershed area (e.g., the mean annual flow) are corrected to the same extent each year. This technique can be interesting if the basin is large and the researcher wishes to compare habitat variability in a scale-free manner without the influence of the river size. Costa et al. (in press) standardised habitat data in this manner to reduce the intersite variability (related to the watershed area) to classify the study sites and construct a habitat suitability model for a native fish species at the mesohabitat scale. Our analyses were focussed on the actual magnitude of the variables associated with the aquatic habitat, including its spatial and temporal variability, and the difference in watershed area was not as relevant as it was in the study by Costa et al.

In this study, we analysed the similarity, the variability and isolation of the classes established a priori to evaluate a 4-mesohabitat-type classification and to detect the classes having the greatest variability. Our results indicate the importance of evaluating habitat classifications because this variability can in turn affect ecohydromorphological and hydro-biological studies that treat the physical habitat as the basis for ecological assessments. The evaluation of habitat classifications is also important for the application of environmental flow studies at the mesohabitat scale. Given the importance of hydro-morphological assessment in rivers, the selection of a suitable mesohabitat classification has substantial relevance to the accuracy and reliability of scientific results and is also substantially relevant to the monitoring budget for the assessment of the ecological status of the area of interest. In future studies, it will likewise be important to evaluate the ecological significance of the proposed mesohabitat classification, especially in Mediterranean streams and rivers. 


\section{ACKNOWLEDGEMENTS}

The collection of the data for this study was partially funded by the Consellería de Medio Ambiente, Agua, Urbanismo y Vivienda, of the Generalitat Valenciana, Spain. Partial funding was furnished by the Institut d'Investigació per a la Gestió Integrada de Zones Costaneres of the Universitat Politècnica de València. We thank Pau Lucio, Rafael Casas, Pascual Puerto, Javier Izquierdo, Consuelo Pérez and Rosa de la Salud for their participation in the field work. We also thank Juan Theureau and Francisco J. Martínez García (Generalitat Valenciana), and Roberto Coll for their help during the development of the study.

\section{REFERENCES}

ALCARAZ-HERNÁNDEZ, J. D. 2011. Estado de las poblaciones de trucha común en ríos de la comunidad valenciana y caracterización de sus hábitats. PhD thesis, Universitat Politecnica de Valencia, Valencia. 169 pp.

ALCARAZ-HERNÁNDEZ, J. D., F. MARTÍNEZCAPEL, M. ARENAS SÁEZ, V. GARÓFANO GÓMEZ. 2009. Relationships between mesohabitat characteristics and brown trout populations in Mediterranean streams (Comunidad Valenciana, Spain). Proceedings of the VII International Symposium on Ecohydraulics. IAHR-Universidad de Concepción. Concepción, Chile.

ALCARAZ-HERNÁNDEZ, J. D., MARTÍNEZ-CAPEL, F., PEREDO, M. \& HERNÁNDEZ-MASCARELL, A.B. 2007. Relaciones entre densidades y biomasas de Salmo trutta fario y mediciones del mesohábitat en tramos trucheros de la Communidad Valenciana. Limnetica, 26 (1): 159-167.

BEISEL J. N., P. USSEGLIO-POLATERA, S. THOMAS \& J. C MORETEAU. 1998. Stream community structure in relation to spatial variation: the influence of mesohabitat characteristics. Hydrobiologia, 389: 73-88.

BISSON, P. A., J. L. NIELSEN, R. A. PALMASON \& L. E. GROVE. 1982. A system of naming habitat types in small streams, with examples of habitat utilization by salmonids during low streamflow. In: Acquisition and utilization of aquatic habitat inventory information. N.B. Armantrout (ed.):
62-73. Symposium proceeding, Portland, Oregon, USA.

BISSON, P. A., J. M. BUFFINGTON \& D. R. MONTGOMERY. 2006. Valley segment, stream reaches, and channel units. In: Methods in stream ecology. F. R. Hauer \& G. A. Lamberti (eds.). 23-49. Academic Press. San Diego. California. USA.

BRENDEN, T. O., L. WANG \& P. W. SEELBACH. 2008. A river valley segment classification of Michigan streams based on fish and physical attributes. Transactions of the American Fisheries Society, 137: 1621-1636.

BROWN, A. V. \& P. P. BRUSSOCK. 1991. Comparisons of benthic invertebrate between riffles and pools. Hydrobiologia, 220: 99-108.

CEN (Comité Européen de Normalisation). 2004. Water quality-Guidance standard for assessing the hydromorphological features of rivers. Final draft prEN 14614, European Standard. 21 pp.

CLIFFORD N. J., O. HARMAR, G. HARVEY \& G. E. PETTS. 2006. Physical habitat, ecohydraulics and river design: a review and case study reevaluation of some popular concepts and methods. Aquatic Conservation: Marine and Freshwater Ecosystems, 16: 389-408.

COSTA, M. 1999. La vegetación y el paisaje en las tierras valencianas. Editorial Rueda, S.L., Madrid.

COSTA, R., F. MARTINEZ-CAPEL, R. MUÑOZMAS, J. D. ALCARAZ-HERNÁNDEZ, V. GARÓFANO-GÓMEZ. 2011. Habitat suitability modelling at mesohabitat scale and effects of dam operation on the endangered Júcar nase, Parachondrostoma arrigonis (river Cabriel, Spain). River Research and Applications. doi:10.1002/rra.1598

DIGBY, P. G. N. \& R. A. KEMPTON. 1987. Multivariate analysis of ecological communities. Chapman and Hall. London. UK. 206 pp.

DOLLOFF, C. A., D. G. HANKIN \& G. H. REEVES. 1993. Basinwide estimation of habitat and fish populations in streams (Technical report). U.S. Department of Agriculture. Forest Service. Southeastern Forest Experiment Station. USA. 25 pp.

ERÖS, T.\& G. D. GROSSMAN. 2005. Effects of within-patch habitat structure and variation on fish assemblage characteristics in the Bernecei stream, Hungary. Ecology of Freshwater Fish, 14: 256266.

EUROPEAN COMMISSION. 2000. Directive 2000/ $60 /$ EC of the European parliament of the council of 23 October 2000 establishing a framework for 
Community action in the field of water policy. $O f$ ficial Journal of the European Communities L327: $1-72$.

FERNÁNDEZ, D., J. BARQUIN \& P. J. RAVEN. 2011. A review of methods characterizing river habitats; Indices or characterisation protocols? Limnetica, 30(2): 217-234.

FLOSI, G. \& F. L. REYNOLDS. 1994. California salmonid stream habitat restoration manual. Second edition. California Department of Fish and Game. Sacramento. USA. 271 pp.

FRISSELL, C. A., W. J. LISS, C. E. WARREN \& M. D. HURLEY. 1986. A hierarchical fremework for stream habitat classification: Viewing streams in a watershed context. Environmental Management, 10: 199-214.

GONZÁLEZ DEL TÁNAGO, M \& D. GARCÍA DE JALÓN. 2006. Propuesta de caracterización jerárquica de los ríos españoles para su clasificación según la Directiva Marco de la Unión Europea. Limnetica, 25: 693-712.

GORTÁZAR, J., P. PARASIEWICZ, C. ALONSOGONZÁLEZ \& D. GARCÍA DE JALÓN. 2011. Physical habitat assessment in the river Tajuña (spain) by means of the MesoHABSIM approach. Limnetica, 30(2): 379-398.

GOSLEE, S. C. \& D. L. URBAN. 2007. The ecodist package for dissimilarity-based analysis of ecological data. Journal of Statistical Software, 22: 1-19.

HANKIN, D. G. \& G. H. REEVES. 1988. Estimating total fish abundance and total habitat area in small streams based on visual estimation methods. Canadian Journal of Fisheries and Aquatic Sciences, 45: 834-844.

HARVEY, G. L. \& N. J. CLIFFORD. 2009. Microscale hydrodynamics and coherent flow structures in rivers: implications for the characterization of physical habitat. River Research and Applications, 25: 160-180.

HAWKINS, C. P., J. L. KERSHNER, P. A. BISSON, M. D. BRYANT, L. M. DECKER, S. V. GREGORY, D. A. McCULLOUGH, C. K. OVERTON, G. H. REEVES, R. J. STEEDMAN \& M. K. YOUNG. 1993. A hierarchical approach to classifying stream habitat features. Fisheries, 18: 3-12.

HAYES, D., E. BAKER, R. BEDNARZ, D. BORGESON JR, J. BRAUNSCHEIDEL, J. BRECK, M. BREMIGAN, A. HARRINGTON, R. HAY, R. LOCKWOOD, A. NUHFER, J. SCHNEIDER, P. SEELBACH, J. WAYBRANT \& T. ZORN. 2003.
Developing a standardized sampling program: the Michigan experience. Fisheries, 28: 18-25.

HILDERBRAND, R. H., A. D. LEMLY, \& C. A. DOLLOFF, 1999. Habitat sequencing and the importance of discharge in inferences. North American Journal of Fisheries Management, 19: 198-202.

JOWETT, I. G. 1993. A method for objetively identifying pool, run, and riffle habitats from physical measurements. New Zeland Journal of Marine and Freshwater Research, 27: 241-248.

LAWA. 2000. Gewässerstrukturgütebewertung in der Bundesrepublik Deutschlan. Verfahren für kleine und mittelgroße Fließgewässer, Berlin. Germany. $145 \mathrm{pp}$.

MEADOR, M. R., T. F. CUFFNEY \& M. E. GURTZ. 1993. Methods for sampling fish communities as part of the National Water-Quality Assessment Program. U.S. Geological Survey Open-File Report 93-104. Raleigh, USA. 40 pp.

MODDE, T., R. C. FORD \& M. G. PARSONS. 1991. Use of a habitat-based stream classification system for categorizing trout biomass. North American Journal of Fisheries Management, 11: 305-311.

MOUTON, A., J. D. ALCARAZ-HERNÁNDEZ, B. DE BAETS, P. GOETHALS, F. MARTÍNEZCAPEL. 2011. Data-driven fuzzy habitat suitability models for brown trout in Spanish Mediterranean rivers. Environmental Modelling \& Software 26: 615-622.

PARASIEWICZ, P. 2007. The MesoHABSIM model revisited. River Research and Applications, 23: 893-903.

PARASIEWICZ, P. \& J. D. WALKER. 2007. Comparison of MesoHABSIM with two microhabitat models (PHABSIM and HARPHA). River Research and Applications, 23(8): 904-923.

PARASIEWICZ, P., J. GORTÁZAR, M. MATEO \& D. GARCÍA DE JALÓN. 2009. MesoHABSIM: Una herramienta eficaz para la gestión de ríos y cuencas fluviales. Tecnología del água, 309: 20-26.

PARDO, I. \& P. D. ARMITAGE. 1997. Species assemblages as descriptors of mesohabitats. Hydrobiologia, 344: 111-128.

PARDO, I., M. ÁLVAREZ, J. CASAS, J. L. MORENO, S. VIVAS, N. BONADA, J. ALBA-TERCEDOR, P. JÁIMEZ-CUÉLLAR, G. MOYÁ, N. PRAT, S. ROBLES, M. L. SUÁREZ, M. TORO \& M. R. VIDAL-ABARCA. 2002. El hábitat de los ríos mediterráneos. Diseño de un índice de diversidad de hábitat. Limnetica, 21: 115-133. 
PLATTS, W. S., W. F. MEGAHAN \& G. W. MINSHALL. 1983. Methods for evaluating stream riparian, and biotic conditions (Technical report). USDA Forest Service. General Technical Report. INT-138. $70 \mathrm{pp}$.

RAVEN, P. J., P. FOX, M. EVERARD, N. T. H. HOLMES \& F. H. DAWSON. 1997. River Habitat Survey: a new system for classifying rivers according to their habitat quality. In: Freshwater quality: Defining the indefinable? P. J. Boon \& D. L. Howell (eds.): 215-234. The Stationery Office, Edinburgh. UK.

REFCOND. 2003. Guidance on establishing reference conditions and ecological status class boundaries for inland surface waters. EU Common Implementation Strategy for the Water Framework Directive. $86 \mathrm{pp}$.

ROPER, B. B. \& D. L. SCARNECCHIA. 1995. Observer variability in classifying habitat types in stream surveys. North American Journal of Fisheries Management, 15: 49-53.

SCHNEIDER, M., M. NOACK, T. GEBLER \& L. KOPECKI. 2010. Handbook for the habitat simulation model CASiMiR. Module CASiMiR-Fish. Base version. Schneider \& Jorde Ecological engineering $\mathrm{GmbH}$-Institut für Wasserbau (Universität Stuttgart). 52 pp.

SCHWARTZ, J. S. \& E. E. HERRICKS. 2008. Fish use of ecohydraulic-based mesohabitat units in a low-gradient Illinois stream: implications for stream restoration. Aquatic Conservation: Marine and Freshwater Ecosystems, 18: 852-866.

SEELBACH, P. W., M. J. WILEY, M. E. BAKER \& K. E. WEHRLY. 2006. Initial classification of river valley segments across Michigan's Lower Peninsula. In: Landscape influences on stream habitats and biological assemblages. R. M. Hughes, L. Wang, \& P. W. Seelbach, (eds.): 25-48 pp. American Fisheries Society, Symposium 48, Bethesda, Maryland. USA.

SNELDER, T. H., A. LEHMANN, N. LAMOUROUX, J. LEATHWICK \& K. ALLENBACH. 2009. Strong influence of variable treatment on the performance of numerically defined ecological regions. Environmental Management, 44: 658-670.

SNELDER, T. H., F. CATTANÉO, A. M. SUREN \& B. J. F. BIGGS. 2005. Is the river environment classification an improved landscape-scale classification of rivers? Journal of the North American Benthological Society, 23: 580-598.
SNELDER, T. H., R. WOODS \& B. J. F. BIGGS. 2005. Improved ecohydrological classification of rivers. River Research and Applications, 21: 609628.

SOWA, S. P., D. D. DIAMOND, R. ABBITT, G. ANNIS, T. GORDON, M. E. MOREY, G. R. SORENSEN \& D. TRUE. 2005. A gap analysis for riverine ecosystems of Missouri (Technical report). USGS National Gap Analysis Program, Final Report, Reston, Virginia. USA. 1675 pp.

STODDARD, J. L., D. V. PECK, S. G. PAULSEN, J. VAN SICKLE, C. P. HAWKINS, A. T. HERLIHY, R. M. HUGHES, P. R. KAUFMANN, D. P. LARSEN, G. LOMNICKY, A. R. OLSEN, S. A. PETERSON, P. L. RINGOLD \& T. R. WHITTIER. 2005. An ecological assessment of western streams and rivers (Technical report). U.S. Environmental Protection Agency, EPA 620/R-05/005, Washington, D.C. USA. 49 pp.

STRAHLER, A. N. 1957. Quantitative Analysis of Watershed Geomorphology. Transactions of the American Geophysical Union, 38: 913-920.

THOMSON, J. R., M. P. TAYLOR \& G. J. BRIERLEY. 2004. Are river styles ecologically meaningful? A test of the ecological significance of a geomorphic river characterization scheme. Aquatic Conservation: Marine and Freshwater Ecosystems, 14: 25-48.

TICKNER, D., P. D. ARMITAGE, M. A. BICKERTON \& K. A. HALL. 2000. Assessing stream quality using information on mesohabitat distribution and character. Aquatic Conservation: Marine and Freshwater Ecosystems, 10: 179-196.

TRAINOR, K. \& M. CHURCH. 2003. Quantifying variability in stream channel morphology. Water Resources Research, 39. 1248, doi:10.1029/2003WR001971.

VADAS, R. L. \& D. J. ORTH. 1998. Use of physical variables to discriminate visually determined mesohabitat types in North American stream. River, 6: 143-159.

VAN SICKLE, J. \& R. M. HUGHES. 2000. Classification strengths of ecoregions, catchments, and geographic clusters for aquatic vertebrates in Oregon. Journal of the North American Benthological Society, 19: 370-384.

VAN SICKLE, J. 1997. Using mean similarity dendrograms to evaluate classifications. Journal of Agricultural, Biological and Environmental Statistics, 2: 370-388. 
WANG, L., P. W. SEELBACH \& R. M. HUGHES. 2006. Introduction to landscape influences on stream habitats and biological assemblages. American Fisheries Society Symposium, 48: 1-23.

WILLIAMS, L. R., M. L. WARREN, S. B. ADAMS,
J. L. ARVAI \& C. M. TAYLOR. 2004. Basin visual estimation technique (BVET) and representative reach approaches to wadeable stream surveys: methodological limitations and future directions. Fisheries, 29: 12-22. 
